\title{
SUSTENTABILIDADE, SOCIEDADE DE RISCO E ALIMENTOS TRANSGÊNICOS: DISPUTAS DEFINITÓRIAS E O PROJETO DE LEI No ${ }^{\circ}$ 4.148/08
SUSTAINABILITY, RISK SOCIETY AND GENETICALLY MODIFIED FOODS: DEFINITIONS DISPUTES AND THE BILL $N^{\circ}$ 4.148/08

\begin{abstract}
${ }^{1}$ Maria Claudia S. Antunes De Souza
${ }^{2}$ João Luiz de Carvalho Botega

\section{RESUMO}

O artigo terá por objeto o exame do Projeto de Lei n. 4.148/08, que altera significativamente a forma de rotulagem dos alimentos transgênicos, substituindo o símbolo atualmente existente por uma frase inserida entre outros dados do rótulo. Como objetivo do artigo, demonstrar que essa proposta, para além de uma mera alteração legislativa de menor importância, está inserida em contexto muito maior e é vem de encontro com a proposta apresentada por Ulrich Beck de que os riscos socialmente reconhecidos seriam alvo e objeto de disputas definitórias que dependeriam muito menos dos conhecimentos científicos a respeito do tema do que efetivamente do jogo politico, que envolve poder, dinheiro, informação e espaço midiático. Além disso, segue-se a afirmação em resposta ao problema da pesquisa de que, à luz do paradigma da sustentabilidade, o PL 4.148/08 representa um retrocesso socioambiental e uma ameaça à construção desse novo imperativo ético. Na metodologia foi utilizado o método indutivo na fase de investigação; na fase de tratamento de dados o método cartesiano e no relatório da pesquisa foi empregada a base indutiva. Foram também acionadas as técnicas do referente, da categoria, dos conceitos operacionais, da pesquisa bibliográfica e do fichamento.
\end{abstract}

Palavras-chave: Sustentabilidade, Sociedade de risco, Alimentos transgênicos, Disputa definitória, $\mathrm{Pl} \mathrm{n}^{\circ}$ 4.148/08

\begin{abstract}
The paper has for object the analysis of the Bill n. 4.148/08, which significantly changes the way the labeling of GM foods, replacing the currently existing symbol by a phrase inserted between other label data. It is the goal of the reserach to show that this proposal, beyond a mere legislative amendment least, is embedded in a much larger context and is living proof of the hypothesis of Professor Ulrich Beck that socially recognized risks would be subject and object of definitions disputes much less depend on scientific knowledge of what actually the political game that involves power, money, information and media space. In addition, it follows the assertion in response to the problem of the research that, in the light of the sustainability paradigm, the PL 4.148/08 represents an environmental setback and itself a threat to the construction of this new ethical imperative. In the methodology we used the inductive method in the investigation phase; in the data processing phase the Cartesian method and in the research report was employed the inductive base. They were also triggered the techniques of reference, category, operational concepts, bibliographic research and book report.
\end{abstract}

Keywords: Sustainability, Risk society, Transgenic foods, Definitions disputes, $\mathrm{Pl} \mathrm{n}^{\circ}$ $4.148 / 08$

\footnotetext{
${ }^{1}$ Doutora em Direito Ambiental e Sustentabilidade pela Universidade de Alicante, Alacant (Espanha). Professora no Curso de Direito da Universidade do Vale do Itajaí - UNIVALI, Santa Catarina (Brasil). E-mail: mclaudia@ univali.br ${ }^{2}$ Mestrando em Ciência Jurídica na Universidade do Vale do Itajaí - UNIVALI, Santa Catarina (Brasil). Professor da Escola do Ministério Público do Estado de Santa Catarina, ESCOLA DO MPSC, Santa Catarina (Brasil). E-mail: joaobotega@gmail.com
} 


\section{INTRODUÇÃO}

Em apertada síntese, o Projeto de Lei $4.148 / 08^{1}$ altera significativamente a forma de indicação nos rótulos de produtos que tenham em sua composição material transgênico, com a substituição do símbolo da transgenia (um "T" maiúsculo no centro de um triângulo da cor amarela) pela indicação "contém transgênico", nos mesmos moldes das demais inscrições do rótulo.

Embora o assunto tenha ganhado relativo destaque na mídia, a imensa maioria daqueles que se colocaram em oposição ao Projeto de Lei em questão o fizeram a partir de uma perspectiva do direito do consumidor ${ }^{2}$. O Instituto Brasileiro de Defesa do Consumidor, por exemplo, iniciou a campanha "Fim da rotulagem dos alimentos transgênicos: diga não!", com o objetivo de pressionar os deputados a rejeitarem a mudança na legislação ${ }^{34}$. Por que esconder do consumidor? Sabe-se que, na prática, a informação vai estar do tamanho de letra

\footnotetext{
${ }^{1}$ No dia 28 de abril de 2015, a Câmara dos Deputados aprovou o Projeto de Lei n. 4.148/08, de autoria do Deputado Federal Luis Carlos Heinze, do Partido Progressista do Rio Grande do Sul (PP-RS), e presidente da Frente Parlamentar da Agropecuária. Foram 320 votos a favor e 135 contra. (Disponível em http://www.idec.org.br/mobilize-se/campanhas/fim-da-rotulagem-dos-alimentos-transgenicos-diga-no, acesso em 10 de agosto de 2015).

${ }^{2}$ Antes ainda do debate atual, a academia já se preocupava com o tema sob esta óptica. Confira-se: BAGGIO, Andreza Cristina; EFING, Antônio Carlos. INFORMAÇÃO PARA O CONSUMO DE ALIMENTOS TRANSGÊNICOS: ATENDIMENTO DA DIGNIDADE DO CIDADÃO BRASILEIRO. Novos Estudos Jurídicos, [S.1.], v. 14, n. 2, p. 54-83, out. 2009. ISSN 2175-0491. Disponível em: <http://www6.univali.br/seer/index.php/nej/article/view/1768/1408>. Acesso em: 02 Ago. 2015.

3 "O direito à informação dos consumidores e consumidoras continua ameaçado! O PL Heinze, que prevê a necessidade de rotulagem dos alimentos que contenham ou sejam produzidos com mais de $1 \%$ de ingredientes transgênicos somente mediante ANÁLISE ESPECÍFICA, entrou na pauta da Câmara do Deputados no dia 28 de abril e foi APROVADO, sendo encaminhado agora ao Senado. Com a aprovação da lei, os símbolos que identificam hoje produtos com OGMs poderão não estar mais presentes nos rótulos, sendo que, para o consumidor final, não será mais possível ter certeza sobre a presença de transgênicos em alimentos por meio da rotulagem, exceto em caso de teste laboratorial específico. "Sabe-se, porém, que a presença do DNA transgênico não é detectável por análise em alimentos processados. Isso significa que, caso a proposta seja aprovada, muitos produtos hoje rotulados passarão a não ser, como margarinas, bolachas, óleos, entre outros. Não só esses alimentos deixarão de ser rotulados, como também aqueles de origem animal alimentados com ração transgênica. Além disso, a responsabilidade por tal análise e pela fiscalização do cumprimento da medida está em aberto" comenta Renata Amaral, pesquisadora em Consumo Sustentável do Idec. Por isso, mudamos o foco da Campanha e precisamos que todos enviem o maior número de mensagens possível aos senadores utilizando a ferramenta ao lado para tentarmos barrar essa aprovação. Mesmo quem já enviou pode mandar novamente, quantas vezes quiser! Caso o projeto de lei seja aprovado, corremos sério risco de saúde, pois compraremos alimentos sem saber se são seguros ou não. Atualmente, cerca de $92,4 \%$ da soja e $81,4 \%$ do milho do País são de origem transgênica. É essa produção crescente e acelerada que leva para a mesa do consumidor um alimento disfarçado ou camuflado que não informa sua real procedência. Nós, consumidores, temos o direito à informação (artigo $6^{\circ}$ do CDC) sobre o que estamos adquirindo ao comprarmos e consumirmos um produto" (Disponível em http://www.idec.org.br/mobilizese/campanhas/fim-da-rotulagem-dos-alimentos-transgenicos-diga-no, acesso em

10 de agosto de 2015).

${ }^{4} \mathrm{O}$ presidente do Instituto, em entrevista a um jornal, enfatizou que "Nossa posição é de total repúdio a essa lei, porque ela fere um direito básico previsto no Código de Defesa do Consumidor, que é o direito à informação" ( EL PAÍS. Câmara aprova lei que dispensa símbolo da transgenia em rótulos. Disponível em: http://brasil.elpais.com/brasil/2015/04/29/politica/1430318732_866908.html. Acesso em 30 jul 2015).
} 
de bula de remédio, e o consumidor vai consumir transgênico sem saber" ${ }^{\text {"5 }}$.

É relevante destacar que os alimentos transgênicos aqueles cujo genoma foi modificado com o objetivo de atribuir-lhe nova característica ou alterar alguma característica já existente, através da inserção ou eliminação de um ou mais genes por técnicas de engenharia genética ${ }^{6}$. Neste sentido, são organismos que sofreram alteração no seu código genético por métodos ou meios que não são naturalmente.

O presente artigo, entretanto, pretende analisar o tema sob outro enfoque e inseri-lo em outro contexto - não sob o prisma do direito do consumidor, apontando uma inegável violação ao direito à informação, mas sim a partir da constatação de que a alteração da rotulagem dos alimentos transgênicos está posta, na verdade, como uma disputa definitória na sociedade de risco.

O problema que se coloca, então, é saber se a alteração dos rótulos dos alimentos transgênicos proposta pelo Projeto de Lei em questão, inserida nesse contexto de disputa definitória, corresponde a um retrocesso socioambiental ${ }^{7}$ e implica um obstáculo à construção do novo imperativo ético representado pelo paradigma da sustentabilidade. Destaca que "o princípio da Sustentabilidade surge como uma resposta à fratura da razão modernizadora e como uma condição para construir uma nova racionalidade produtiva", fundada no potencial ecológico e em novos sentidos de civilização ${ }^{8}$ a partir da diversidade cultural do gênero humano.

Para responder esta questão, a pesquisa passará a estudar seus temas centrais, quais sejam: a) o paradigma da sustentabilidade como forma de garantir a sobrevivência da vida na Terra; b) a noção de sociedade de risco, desenvolvida por Ulrich Beck, que aponta para a incrível ameaça à humanidade que o desenvolvimento do conhecimento científico gerou, sobretudo em decorrência da catástrofe ambiental que se avizinha; e c) por fim, o próprio Projeto de Lei n. 4.148/08, para efetivamente compreendê-lo a partir das categorias das disputas definitórias na sociedade de risco e do paradigma da sociedade.

Dentre os objetivos da pesquisa estão: analisar as características da sociedade de

5 Câmara aprova projeto que muda rótulo de produtos transgênicos. Disponível em: $\quad$ http://g1.globo.com/politica/noticia/2015/04/camara-aprova-projeto-que-muda-rotulo-de-produtostransgenicos.html Acesso em 30 jul 2015.

${ }^{6}$ MARINHO, Carmem Luiza Cabral. Discurso polissêmico sobre plantas transgênicas no Brasil: estado da arte. Tese (Doutorado). Escola Nacional de Saúde Pública. Fiocruz. Rio de Janeiro. 2003.

${ }^{7}$ Sobre o tema recomenda-se a leitura: PRIEUR, Michel. O princípio da "não regressão" no coração do direito do homem e do meio ambiente. Revista de Estudos Jurídicos. v. 17, n. 1 (2012). Disponível em http://www6.univali.br/seer/index.php/nej/article/view/3634/2177.

${ }^{8}$ HUNTIGTON, Samuel P. Choque de civilizaciones?: texto crítico de Pedro Martinez Montávez. Madrid: Tecnos, 2002. p. 25. 
risco, em especial o contexto em que ocorrem as disputas definitórias em torno dos riscos socialmente construídos; compreender o paradigma da sustentabilidade e sua importância para a proteção e promoção de uma vida segura, digna e ecologicamente equilibrada para todos os seres; e verificar se a modificação legislativa proposta é de fato uma disputa definitória e, em caso positivo, se está adequada ao novo imperativo ético da sustentabilidade.

Justifica-se o estudo diante da relevância da análise jurídica do Projeto de Lei n. 4.148/08, sob enfoque a partir da constatação de que a alteração da rotulagem dos alimentos transgênicos está posta como uma disputa definitória na sociedade de risco, à luz da sustentabilidade; além de que abarca temática de debate na atualidade do cenário jurídico global.

Registra-se, por derradeiro, que quanto à metodologia, o relato dos resultados será composto na base lógica Indutiva ${ }^{9}$.

\section{BREVES CONSIDERAÇÕES ACERCA DO PARADIGMA DA SUSTENTABILIDADE}

Numa sociedade de risco e extremamente complexa, em que o capital tem mais valor que o homem e em que a natureza é instrumentalizada para servir a alguns, colocando em risco a própria preservação da espécie humana e da vida em geral no planeta, surge a ideia da sustentabilidade como novo paradigma axiológico transnacional ${ }^{10}$ para a humanidade e sua relação com a Terra.

O primeiro ponto para compreender o que é efetivamente este novo paradigma diz respeito à gravidade da atual crise da civilização humana: diferentemente daquelas vivenciadas em períodos da civilização antiga, a crise da sociedade contemporânea não se restringe a indivíduos, governos ou instituições sociais, uma vez que atinge dimensões planetárias. Efetivamente, pela primeira vez na história do homem vivencia-se sério risco da extinção não só da espécie humana, mas também da destruição da própria vida existente no planeta.

\footnotetext{
9 “[...] pesquisar e identificar as partes de um fenômeno e colecioná-las de modo a ter uma percepção ou conclusão geral [...]". (PASOLD, Cesar Luis. Metodologia da pesquisa jurídica: teoria e prática. 11 ed. Florianópolis: Conceito editorial/Milleniuum, 2008. p. 86).

${ }^{10}$ FERRER, Gabriel Real; GLASENAPP, Maikon Cristiano; CRUZ, Paulo Márcio. Sustentabilidade: um novo paradigma para o direito. Novos Estudos Jurídicos, [S.1.], v. 19, n. 4, p. 1433-1464, dez. 2014. ISSN 21750491. Disponível em: 〈http://www6.univali.br/seer/index.php/nej/article/view/6712/3833〉. Acesso em: 3 Ago. 2015. p. 1.455.
} 
Para Juarez Freitas ${ }^{11}$, os dramas da civilização contemporânea, sobretudo os socioambientais (pobreza extrema, desigualdade social, aquecimento global, insegurança alimentar, exaurimento dos recursos naturais etc.), não podem ser entendidos e enfrentados de maneira isolada (por apenas um grupo de pessoas ou por uma parte do conhecimento humano) nem estática (como se não estivesse em constante transformação), mas sim receber uma abordagem sistemática, empírica e integrada, combinando elementos sociais, ambientais, econômicos e jurídico-políticos. Desse modo, a sustentabilidade deve emergir como uma "racionalidade dialógica, interdisciplinar, criativa, antecipatória, mediadora de consequências e aberta"

Por outro lado, a sustentabilidade ${ }^{13}$ deve ser pensada sempre em uma perspectiva global, já que os danos ambientais não conhecem fronteiras geográficas. Assim, de nada adiantaria que um determinado país um uma determinada região desenvolvesse práticas sustentáveis se essas práticas não se espraiarem por todo o mundo. Segundo Leonardo Boff ${ }^{14}$,

A sustentabilidade deve ser pensada numa perspectiva global, envolvendo todo o planeta, com equidade, fazendo que o bem de uma parte não faça à custa do prejuízo da outra. Os custos e os benefícios devem ser proporcional e solidariamente repartidos. Não é possível garantir a sustentabilidade de uma porção do planeta deixando de elevar, na medida do possível, as outras partes ao mesmo nível ou próximo a ele.

Nesse sentido, para se entender efetivamente a fundamental importância da

\footnotetext{
${ }_{12}^{11}$ FREITAS, Juarez. Sustentabilidade: direito ao futuro. 2. ed. Belo Horizonte: Fórum, 2012. p. 40.

12 FREITAS, Juarez. Sustentabilidade: direito ao futuro. p. 29.

13 Em 1972, por consequência, convocou-se a Conferência das Nações Unidas para o Meio Ambiente Humano, realizada em Estocolmo, que produziu a Declaração sobre Ambiente Humano, estabelecendo princípios para questões ambientais internacionais, incluindo direitos humanos, gestão de recursos naturais, prevenção da poluição, dando surgimento ao direito ambiental internacional, elevando a cultura política mundial de respeito à ecologia, e servindo como o primeiro convite para a elaboração de novo paradigma econômico e civilizatório para os países. Na reunião de Estocolmo, originou-se o momento de constatação e alerta global sobre a degradação ambiental. A Declaração da Conferência da ONU sobre o Meio Ambiente descreveu assim: "defender e melhorar o meio ambiente para as atuais e futuras gerações se tornou uma meta fundamental para a humanidade". Deste modo, a conferência de Estocolmo criou a Comissão Mundial sobre Meio Ambiente e Desenvolvimento, inaugurando a agenda ambiental, permitindo iniciar a relação entre ambiente e desenvolvimento, dando as primeiras referências de Desenvolvimento Sustentável, que na época tinha por termo "ecodesenvolvimento". Tratou-se dos primeiros passos para o pensamento verde. Em 1983, o Relatório de Brundtland, feito pela chefe da Comissão Mundial do Meio Ambiente e Desenvolvimento, conceituou Desenvolvimento Sustentável como: "a satisfação das necessidades do presente sem comprometer a capacidade das gerações futuras de satisfazer em suas próprias necessidades". O Relatório complementa que: "um mundo onde a pobreza e a desigualdade são endêmicas estará sempre propenso à crises ecológicas, entre outras", "o Desenvolvimento Sustentável requer que as sociedades atendam às necessidades humanas tanto pelo aumento do potencial produtivo como pela garantia de oportunidades iguais para todos". Relatório da Comissão Mundial sobre Meio Ambiente e Desenvolvimento. Relatório Brundtland, "Nosso Futuro Comum. Disponível em: http://www.un.org/documents/ga/res/42/ares42-187.htm. Acesso em: 15 de agosto de 2015.

14 BOFF, Leonardo. Sustentabilidade: O que é - O que não é. 2. Ed. Petrópolis, Rio de Janeiro: Vozes, 2013. p. 17.
} 
sustentabilidade para a garantia do próprio futuro da humanidade, é necessário romper com os paradigmas até agora vigentes, que se mostraram insuficientes e até mesmo prejudiciais para a conservação da vida (sobretudo a humana) na Terra.

Assim, primeiramente é preciso desenvolver um senso de urgência a respeito da grave crise socioambiental atualmente existente, chamando à responsabilidade conjunta e solidária o Estado e cada um dos cidadãos. Embora uma visão a longo prazo seja fundamental, não há mais como esperar que uma nova geração (mais bem-educada para o meio ambiente) surja para salvar o planeta, pois os problemas ocorrem aqui e agora e cabe a esta geração o desafio de superá-los com suas próprias forças.

Ademais, a visão de mundo, holística ${ }^{15}$, constitui um novo imperativo ético ${ }^{16}$ para a humanidade, baseada em critérios de solidariedade "sincrônica com a geração atual, diacrônica com as futuras gerações e em sintonia com a natureza" ${ }^{\text {"17 }}$, e deve implicar um novo arranjo cultural para a sociedade contemporânea, que represente significativas mudanças em estruturas sociais e instituições político-jurídicas construídas em outras épocas.

A sustentabilidade como novo paradigma aparece como critério normativo para a reconstrução da ordem econômica (um novo sistema econômico mais justo, equilibrado e sustentável) da organização social (modificando a estrutura social e a organização da sociedade - equidade e justiça social) do meio ambiente (possibilitando a sobrevivência do homem em condições sustentáveis e digna - respeito ao meio ambiente) ${ }^{18}$.

Tendo em vista a insuficiência de apenas um setor, isolado, do conhecimento humano para dar conta dos novos desafios enfrentados pela humanidade, a sustentabilidade, a fim de representar uma verdadeira mudança de mentalidade ${ }^{19}$ do ser humano, não pode ser estudada apenas sob o influxo de sua dimensão ambiental ou ecológica, ganhando relevo as dimensões social e econômica do novo paradigma.

Não há dúvida, hoje, que os problemas ambientais estão quase sempre ligados a problemas de ordem social, de modo que somente se pode pensar em melhorar as condições

\footnotetext{
${ }^{15}$ CAPRA, Fritjof. O ponto de mutação. São Paulo: Cultrix, 2012. p. 17.

${ }^{16}$ FERRER, Gabriel Real; GLASENAPP, Maikon Cristiano; CRUZ, Paulo Márcio. Sustentabilidade: um novo paradigma para o direito. Novos Estudos Jurídicos, p. 1459.

${ }^{17}$ FERRER, Gabriel Real; GLASENAPP, Maikon Cristiano; CRUZ, Paulo Márcio. Sustentabilidade: um novo paradigma para o direito. Novos Estudos Jurídicos, p. 1459.

${ }^{8}$ FERRER, Gabriel Real; GLASENAPP, Maikon Cristiano; CRUZ, Paulo Márcio. Sustentabilidade: um novo paradigma para o direito. Novos Estudos Jurídicos, p. 1459.

${ }^{9}$ SOUZA, Maria Cláudia da Silva Antunes de. Impressões sobre o legado da Rio+20. Revista Eletrônica Direito e Política, Programa de Pós-Graduação Stricto Sensu em Ciência Jurídica da UNIVALI, Itajaí, v.7, n.3, $3^{\circ}$ quadrimestre de 2012. p. 2178. Disponível em: www.univali.br/direitoepolitica.. Acesso 03 de agosto de 2015.
} 
ambientais do planeta quando isto vier acompanhado da elevação da condição de vida de boa parte da população humana, hoje extremamente marginalizada. Ademais, não se poderá combater a pobreza e a concentração de renda - e, logo, também os problemas ambientais sem que se questione o modo de produção capitalista atual, de incentivo desenfreado ao consumismo e de lucros ilimitados.

$\mathrm{Na}$ era do hiperconsumo e da soberania do mercado, o sonho da felicidade materializado no ato de consumo acarreta a cada dia mais exclusão social. Eis a face oculta do hiperconsumo. Para atender o frenesi consumista do hiperconsumidor é preciso imprimir um ritmo cada vez mais frenético de produção; esse ritmo de hiperprodução atinge o meio ambiente, fonte de recursos e matéria prima, gerando cenários de degradação ambiental decorrentes de resíduos industriais, contaminação tóxica, lixo em larga escala, poluição do ar e das águas; contudo, como as regras do jogo são apitadas pelo mercado, a lógica do lucro ilimitado deixa de lado qualquer princípio ético de justiça social, trazendo como corolário uma distribuição desigual entre classes sociais dos riscos decorrentes desses cenários de degradação ${ }^{20}$.

Diante desse quadro, também o direito é (ou deve ser) afetado pelo paradigma da sustentabilidade, não só no momento da elaboração de novas leis, mas também com a adequação e adaptação de conceitos e instituições jurídicas já existentes à nova categoria ${ }^{21}$.

A sustentabilidade, assim, transformar-se-ia em um princípio constitucional de aplicação direta e imediata, quase que um "valor supremo", o qual estabeleceria a responsabilidade solidária do Estado, da sociedade e de cada ser humano pela realização e efetivação de um desenvolvimento socialmente inclusivo, ambientalmente limpo, ético e eficiente $^{22}$.

Para que isso se concretize, além de investimentos e incentivos à educação ambiental e sustentável, mostra-se premente também aperfeiçoar os mecanismos de prevenção dos danos e riscos ambientais, superando o velho enfoque meramente repressivista que vigorou por

\footnotetext{
${ }^{20}$ RAMMÊ, Rogério Santos. Justiça ambiental, marxismo ecológico e suas relações com o direito socioambiental. Revista Eletrônica Direito e Política, Programa de Pós-Graduação Stricto Sensu em Ciência Jurídica da UNIVALI, Itajaí, v.6, n.1, $1^{\circ}$ quadrimestre de 2011. Disponível em: www.univali.br/direitoepolitica. p. 220.

${ }^{21}$ Com isso, para o campo jurídico, a sustentabilidade impõe não apenas a revisão de seus esquemas conceituais e estruturais, como também apresenta um novo ator ao direito (desconhecido até então), as gerações futuras, ou seja, o dilema da sustentabilidade ultrapassa em muito a lógica estruturante do Estado Constitucional Moderno e do Direito nacional, submetidos aos estritos limites de territorialidade de suas fórmulas sancionatórias. Ademais, a sustentabilidade impõe o princípio da solidariedade entre as gerações, "obrigando as gerações presentes a incluir como medida de ação e de ponderação os interesses das gerações futuras" (REAL FERRER, Gabriel Real Ferrer; GLASENAPP, Maikon Cristiano; CRUZ, Paulo Márcio. Sustentabilidade: um novo paradigma para o direito. Novos Estudos Jurídicos, p. 1461).

${ }^{22}$ FREITAS, Juarez. Sustentabilidade: direito ao futuro. p. 41.
} 
algum tempo no direito ambiental. Assim, a sustentabilidade exigirá do Poder Público ações mais efetivas de orientação e fiscalização de empreendimentos potencialmente poluidores, sob pena de o Estado se tornar corresponsável pelos danos eventualmente causados. Deve-se evoluir, então, para uma ideia de responsabilidade integral do Estado, por meio do qual o Poder Público não poderá apresentar nenhuma escusa para afastar sua responsabilidade.

E o alcance desse objetivo exige primeiramente que o Estado brasileiro livre-se de seus antigos vícios, como bem denuncia Juarez Freitas ${ }^{23}$, superando os autoritarismos, coronelismos, patrimonialismos e omissivismos políticos, tão presentes no contexto político nacional, de norte a sul do país. A separação daquilo que é público (e, portanto, de todos) do que é privado, sem que um interfira na esfera decisória do outro, é o primeiro passo que deve ser dado na construção de um Estado efetivamente sustentável.

A partir daí se pode edificar, verdadeiramente, um novo direito, com a previsão, por exemplo, de licitações sustentáveis, em que o Poder Público, por meio de seus representantes democraticamente eleitos, esteja mais preocupado com os impactos socioambientais de suas obras e ações do que com valores meramente monetários ou limites orçamentários, e muito menos com dividendos político-eleitoreiros daquilo que faz ou deixa de fazer.

Enfim, a sustentabilidade, enquanto nova ética humana, deve ser fomentada e estimulada para que a sociedade de risco hodierna não dê o passo adiante no precipício em que a humanidade se colocou.

\section{A SOCIEDADE DE RISCO DE ULRICH BECK E SUAS CARACTERÍSTICAS}

O termo "sociedade de risco" ganhou destaque e foi introduzido no debate acadêmico a partir da conhecida obra "Sociedade de risco: ruma a uma outra modernidade" 24 , do sociólogo alemão e professor da Universidade de Munique Ulrich Beck, lançado no ano de 1986. As ideias e teses centrais do livro, mesmo passados quase trinta anos de sua primeira edição, ainda são extremamente atuais e de fundamental importância para o entendimento da sociedade contemporânea ${ }^{25}$.

Seria inviável, todavia, expor com precisão e rigor metodológico todo o pensamento do Beck nesta pesquisa, de modo que o texto se contentará a uma breve exposição das

\footnotetext{
${ }^{23}$ FREITAS, Juarez. Sustentabilidade: direito ao futuro. p. 175-176.

${ }^{24}$ BECK, Ulrich. Sociedade de risco: rumo a uma outra modernidade. São Paulo: Editora 34, 2011.

${ }^{25}$ ORSELLI, Helena Maria Zanetti de Azeredo e ARAUJO, Roseana Maria Alencar de. Estados transnacionais: aspectos destacados da proposta de Ulrich BecK. Revista Eletrônica Direito e Política, Programa de PósGraduação Stricto Sensu em Ciência Jurídica da UNIVALI, Itajaí, v.7, n.3, $3^{\circ}$ quadrimestre de 2012. Disponível em: www.univali.br/direitoepolitica. Acesso 03 de agosto de 2015.
} 
principais características da sociedade de risco e, sobretudo, a indicar de como elas tem ligação umbilical com o objeto do projeto de lei em análise.

"Na modernidade tardia, a produção social de riqueza é acompanhada sistematicamente pela produção social de riscos"26, assim Beck abre a primeira parte de seu livro. Na modernidade reflexiva (ou segunda modernidade) - que não supera a sociedade de classes de cunho marxista, mas sobrepõe-se a ela -, o desenvolvimento técnico-econômico ou científico acaba por aprisionar a sociedade naquilo que a prometia libertar: o progresso das ciências, que havia prenunciava o fim da escassez material e o completo domínio da natureza pelo homem, atingiu um determinado patamar em que tem, na verdade, gerado riscos ambientais, nucleares, genéticos, químicos, sociais e políticos que colocam em dúvida a sustentabilidade da vida na Terra, ao tempo em que a miséria e a desigualdade social só aumentam.

Em uma sociedade que a qualquer momento pode ser aniquilada, a categoria da incerteza passa a ser a peça chave para entender o desenvolvimento das forças produtivas do mundo globalizado. Quando se pondera que uma bomba nuclear ou, ainda, uma guerra química ou biológica possa, em questão de dias ou mesmo horas, dizimar a vida humana na Terra, percebe-se por que Beck considera a sociedade de risco como uma sociedade catastrófica. Mas não há como confundir risco com catástrofe, pois o risco é, na verdade, a possibilidade da existência ou da ocorrência da catástrofe, e não esta em si, e é justo por isso que os riscos geram medos e incertezas. E estes medos e estas incertezas, por sua vez, por se tratarem de sentimentos, podem ser instrumentalizados e utilizados para os mais variados fins, inclusive políticos e ideológicos.

Não há dúvida de que riscos e perigos existiram durante toda a existência da humanidade; o que marca e distingue os riscos da sociedade contemporânea daqueles ocorridos na antiguidade, no entanto, é que na sociedade de risco estes são causados pelo ("progresso" do) próprio homem e colocam sob ameaça toda a humanidade, como nos exemplos da fissão nuclear e do aquecimento global. Assim, mesmo países ou regiões que em tese estariam livres ou imunes a certos riscos, acabam se tornando também vítimas destes, porque os danos ambientais não conhecem fronteiras geográficas. Conforme explica Beck ${ }^{27}$, os riscos e ameaças atuais diferenciam-se de seus equivalentes medievais "fundamentalmente por conta da globalidade de seu alcance" e, também, em face de "suas causas modernas. São riscos da modernização. São um produto de série do maquinário industrial do progresso,

26 BECK, Ulrich. Sociedade de risco: rumo a uma outra modernidade. p. 23.

${ }^{27}$ BECK, Ulrich. Sociedade de risco: rumo a uma outra modernidade. p. 26. 
sendo sistematicamente agravados com seu desenvolvimento ulterior”.

As concepções do sociólogo alemão sobre a sociedade de risco são, por ele, sistematizadas e articuladas em cinco teses centrais:

a) riscos são diferentes de riquezas: embora os estratos sociais mais vulneráveis estejam mais suscetíveis aos riscos (há uma força de atração entre pobreza extrema e risco extremo), toda a humanidade - mesmo aqueles mais ricos - podem sofrer suas consequências e, por isso, participam e estão envolvidos no processo de construção social dos riscos. "Sofrer o impacto e não sofrer o impacto não se polarizam como ter propriedade e não a ter", resume Beck $^{28}$. Diferentemente do que acontece em uma sociedade de classes, não há uma oposição entre "afetados e não afetados", mas sim, na melhor das hipóteses, entre "afetados e aindanão-afetados". Além disso, como os riscos são fruto do desenvolvimento tecnológico e científico do homem, acabam por ser geralmente apresentados, de início, como algo positivo, benéfico e proveitoso para a sociedade em geral, ganhando, assim, a marca da invisibilidade (pois até que se tornem uma ameaça passam quase sempre despercebidos), o que os tornam ainda mais perigosos e perniciosos. Desse modo, por serem em regra inicialmente imperceptíveis, e essa percepção somente pode ser guiada pelo conhecimento, os riscos "podem ser alterados, diminuídos ou aumentados, dramatizados ou minimizados no âmbito do conhecimento e estão, assim, em certa medida, abertos a processos sociais de definição". ${ }^{29}$

b) os riscos possuem efeito bumerangue: com a distribuição dos riscos nos mais variados estratos sociais, inclusive aqueles que os produzem estão sujeitos a sofrer as consequências das ameaças que criaram (por exemplo, o proprietário de uma grande indústria petroquímica ou um grande desmatador sofrem também com o aquecimento global). Logo, esse efeito bumerangue dos riscos implode o tradicional esquema de classes, pois nem mesmo os ricos e poderosos estão seguros diante das ameaças globais. Os riscos da modernização, cedo ou tarde, como bem observa Beck ${ }^{30}$, gerará uma unidade entre culpado e vítima, já que, em outro exemplo, uma hipotética guerra nuclear aniquilará, a rigor, inclusive o agressor. Ademais do efeito bumerangue, os riscos também são universais e supranacionais, o que significa dizer que não podem ser compreendidos pelo sistema e pela lógica do Estado-nação.

c) os riscos civilizatórios são um barril de necessidades sem fundo: diferentemente dos outros modelos de sociedade, em que se lutava contra a fome, a escassez e outras necessidades (que podem ser eventualmente saciadas e satisfeitas), os riscos são

\footnotetext{
${ }^{28}$ BECK, Ulrich. Sociedade de risco: rumo a uma outra modernidade. p. 47.

${ }^{29}$ BECK, Ulrich. Sociedade de risco: rumo a uma outra modernidade. p. 27.

30 BECK, Ulrich. Sociedade de risco: rumo a uma outra modernidade. p. 45.
} 
autoproduzíveis e, por isso, intermináveis, infinitos. Beck ${ }^{31}$ aqui utiliza-se de um conceito (sociológico) de Luhmann para dizer que a economia, na sociedade de risco, torna-se autorreferencial, ou seja, ela independe do ambiente da satisfação humana. Em outras palavras, na disputa desenfreada do capitalismo moderno, riscos gerarão cada vez mais riscos, até que um deles se concretize em forma de catástofre.

d) na sociedade de risco, é a consciência que determina a existência: Beck propõe uma atualização ou revisão da tese marxiana de que a consciência é determinada pela(s) (condições materiais da) existência ${ }^{32}$. Esse velho esquema é válido para as sociedades de classe; na sociedade de risco, a própria existência do ser humano concreto e da humanidade em geral depende do conhecimento da ocorrência de situações de ameaça as quais estejam afetados. Por consequência, o conhecimento daquilo que é ou pode vir a ser um risco adquire enorme relevância política.

e) o potencial político das catástrofes (a politização dos riscos socialmente reconhecidos): no interior do processo social de reconhecimento da existência de um risco encontra-se um "peculiar ingrediente político explosivo: aquilo que até há pouco era tido por apolítico torna-se político - o combate às "causas" no próprio processo de industrialização",33. É nesse contexto que emergem as disputas definitórias não apenas acerca da existência das ameaças, mas sobretudo em torno da extensão, do grau e da urgência dos riscos. Nessas disputas não importam apenas eventuais problemas de saúde resultante daquele risco concreto, mas, sobretudo os efeitos colaterais sociais, econômicos e políticos do reconhecimento social da ameaça: perdas de mercado, fuga de capital, abertura de novos

mercados, custos políticos e econômicos de grande monta, perda de prestígio social etc. Os riscos, então, implicam uma verdadeira reorganização do poder e da responsabilidade, em que o estado de exceção ameaça converter-se em normalidade ${ }^{34}$. Tome-se, por exemplo, o caso do aquecimento global: este é um risco que está no centro de uma enorme disputa definitória global a respeito de sua extensão, grau e urgência. Indústrias e investidores podem perder

31 BECK, Ulrich. Sociedade de risco: rumo a uma outra modernidade. p. 28.

32 "Assim, a moral, a religião, a metafísica e todo o restante da ideologia, bem como as formas de consciência a elas correspondentes, perdem de logo toda a aparência de autonomia. Não têm história, não têm desenvolvimento; ao contrário, são os homens que, desenvolvendo sua produção material e suas relações materiais, transformam, com a realidade que lhes é própria, seu pensamento e também os produtos do seu pensamento. Não é a consciência que determina a vida, mas sim a vida que determina a consciência. Na primeira forma de considerar as coisas, partimos da consciência como sendo o indivíduo vivo; na segunda, que corresponde à vida real, partimos dos próprios indivíduos reais e vivos, e consideramos a consciência unicamente como a sua consciência" (MARX, Karl; ENGELS, Friedrich. A ideologia alemã. 3. ed. São Paulo: Martins Fontes, 2007. p. 19-20).

${ }^{33}$ BECK, Ulrich. Sociedade de risco: rumo a uma outra modernidade. p. 28.

${ }^{34}$ BECK, Ulrich. Sociedade de risco: rumo a uma outra modernidade. p. 28. 
bilhões de dólares caso o aquecimento global seja reconhecido socialmente como um risco grave (que de fato o é) à sobrevivência do homem no planeta, e por isso investem também em contrainformação para dissuadir parte da opinião pública acerca da extensão e da urgência dessa ameaça civilizatória.

E é desse contexto que brotam duas consequências para a sociedade contemporânea. Primeiro, surgem desafios inteiramente novos à democracia. Ulrich Beck observa que a sociedade de risco traz consigo uma perigosa tendência a um totalitarismo que é "legitimado" pela defesa diante do perigo, a qual, com a incumbência de evitar o pior, acaba provocando algo ainda pior.

Em segundo lugar, há o fim da contraposição entre natureza e sociedade: problemas ambientais não são problemas apenas do meio ambiente, mas problemas "sociais, problemas do ser humano, de sua história, de suas condições de vida, de sua relação com o mundo e com a realidade, de sua constituição econômica, cultural e política» ${ }^{35}$. Em outras palavras e em síntese, a natureza politizou-se.

Feitas essas observações introdutórias, pode-se já enxergar em que contexto está inserido o projeto de lei objeto do presente artigo, o qual passará a ser analisado a seguir.

\section{O PL 4.148/08: DISPUTAS DEFINITÓRIAS EM TORNO DOS ALIMENTOS TRANSGÊNICOS (E SEUS RISCOS)}

O Projeto de Lei 4.148 foi proposto pelo Deputado Luis Carlos Heinze no ano de 2008 com o objetivo de alterar a redação do artigo 40 da Lei n. 11.105/2005, o qual estabelece que "Os alimentos e ingredientes alimentares destinados ao consumo humano ou animal que contenham ou sejam produzidos a partir de $\mathrm{OGM}^{36}$ ou derivados deverão conter informação nesse sentido em seus rótulos, conforme regulamento”. Esses regulamentos são o Decreto n. 4.680/2003 e a Portaria n. 2.658/2003, que definem que os rótulos de produtos que contenham mais de um por cento de sua composição formada por organismos geneticamente modificados devem indicar, além de uma série de outras especificações, um triângulo da cor amarela e com bordas pretas, de tamanho mínimo de $0,4 \%$ da área do painel principal da rotulagem, com a letra “T”' grafada em seu interior.

O PL ora em exame pretende, como visto, substituir essa advertência apenas pela frase “(nome do produto) transgênico" ou “contém (nome do ingrediente) transgênico", a qual

\footnotetext{
${ }^{35}$ BECK, Ulrich. Sociedade de risco: rumo a uma outra modernidade. p. 99.

${ }^{36}$ Sigla para Organismos Geneticamente Modificados.
} 
deveria ser grafada "em destaque" e de forma legível no rótulo. O projeto original, contudo, não especifica o que seria o "destaque" dessa inscrição, pois não fixa tamanhos mínimos para o texto $^{37}$

Para se efetivamente compreender em que contex to se insere o projeto de lei em questão, é de extrema importância esmiuçar a justificativa apresentada pelo proponente da modificação legislativa.

Primeiramente, é curioso observar que o autor do PL refere, logo de início, que "a questão da biotecnologia no Brasil foi extremamente politizada" ${ }^{38}$, como se a sua própria posição não fosse também política, mas apenas científica ou, pior, "neutra".

Demais disso, o parlamentar menciona que a atual rotulagem dos produtos transgênicos, em vez de esclarecer o consumidor, o confunde, induz a erro, a falso entendimento ou a conhecimento de conteúdo inútil. O projeto, no entanto, no lugar de propor uma campanha de conscientização a respeito dos alimentos geneticamente modificados e de como reconhecer o símbolo que indica a presença de OGM no alimento, pretende mascarar e esconder essa informação no meio das dezenas de outros dados constantes das etiquetas dos produtos.

Especificamente quanto à necessidade de aposição do símbolo no rótulo, o deputado Luis Carlos Heinze justificou que:

Quanto a inserção de símbolo junto à informação de transgênia, conforme disciplinado no Decreto $\mathrm{n}^{\circ} 4.680 / 03$ e na Portaria $\mathrm{n}^{\circ}$ 2.658/03, julgamos inapropriada a sua utilização para indicação da presença de DNA ou proteína resultante da modificação genética, pelos motivos que seguem.

As normas de rotulagem de alimentos estabelecidas no Mercosul e no Codex Alimentarius, não apresentam dispositivos específicos de rotulagem dos produtos produzidos a partir de organismos geneticamente modificados e seus derivados. As exigências do Decreto $\mathrm{n}^{\circ} 4.680 / 03$ e da Portaria $\mathrm{n}^{\circ} 2.658 / 03$ provocam sérios problemas nas relações comerciais internacionais, uma vez que o Brasil é o único país do mundo a adotar um símbolo de alerta em produtos aprovados para consumo humano.

As normas brasileiras não se baseiam em nenhum precedente internacional ao instituir o símbolo, que de resto, somente agrega

\footnotetext{
${ }^{37}$ Uma emenda legislativa apresentada posteriormente estabeleceu que a inscrição deve atender ao tamanho mínimo de letra definida no Regulamento Técnico de Rotulagem Geral de Alimentos Embalados, ou seja, a frase será incluída como qualquer outra no rótulo do produto.

${ }^{38}$ Justificativa ao Projeto de Lei n. 4.148/08, de autoria do Deputado Federal Luiz Carlos Heize. Disponível em: http://www.camara.gov.br/proposicoesWeb/prop_mostrarintegra;jsessionid=1D6CAC10CE394E918FFE3A476 $\underline{8}$

11549B.proposicoesWeb1?codteor=605180\&filename=Tramitacao-PL+4148/2008. Acesso em 3 de ago 2015.
} 
valor negativo ao produto.

Cabe ainda ressaltar que a apresentação gráfica (formato e cores) do símbolo disciplinado na Portaria $\mathrm{n}^{\circ} 2.658$, de 22 de dezembro de 2003, é utilizada em placas de advertência, atenção e existência de risco, afixadas em locais de perigo, radiação, eletricidade, explosão, entre outros.

Assim, o símbolo em questão vincula o alimento, que contenha DNA ou proteína obtida através de organismo geneticamente modificado, a circunstâncias de perigo, nocividade, cuidado, alerta, e outras mais para as quais a apresentação gráfica é usualmente destinada.

Esta correspondência entre o símbolo (triângulo amarelo e preto) e suposto "risco" de consumo afeta a imagem de qualidade dos produtos, bem como, a exigência da cor amarela gera altos custos com embalagens, haja vista que, muitas vezes, esta cor não compõe a rotulagem usual dos produtos 39 .

Uma série de objeções jurídicas e científicas poderiam ser levantadas a esse trecho das razões do autor do projeto de lei recentemente aprovado na Câmara dos Deputados, mas não é objetivo do presente ensaio problematizar a questão da segurança do consumo de alimentos transgênicos, até porque sobre isso há farto material publicado. O que se tenta demonstrar aqui, com efeito, é que essa proposta, para além de uma mera alteração legislativa de menor importância, está inserida em um contexto muito maior e é prova viva do acerto da hipótese de Ulrich Beck de que os riscos socialmente reconhecidos seriam alvo e objeto de disputas definitórias que dependeriam muito menos dos conhecimentos científicos objetivos a respeito do tema do que efetivamente do jogo político tradicional, que envolve poder, dinheiro, informação e espaço midiático. Além disso, segue-se a afirmação de que, à luz do paradigma da sustentabilidade, o PL 4.148/08 representa um retrocesso socioambiental e ele mesmo uma ameaça à construção desse novo imperativo ético.

Nessa senda, é interessante observar que o autor do projeto de lei se refere especificamente que a apresentação gráfica do símbolo que representa os alimentos transgênicos é semelhante ao modelo utilizado para outras placas que indicam a existência de risco, como as que indicam locais de perigo, radiação, eletricidade, explosão etc, e que isso "vincularia" o alimento geneticamente modificado a circunstância de perigo ou nocividade.

Causa estranheza, todavia, que em vez de propor, então, um novo símbolo para distinguir os alimentos transgênicos - como seria de se esperar diante da justificativa apresentada -, o PL simplesmente o substitui por uma simples frase que pode ser alocada nos mesmos moldes dos demais ingredientes do produto.

Assim, a retirada do símbolo dos rótulos não só subtrai o direito à informação do

\footnotetext{
${ }^{39}$ Justificativa ao Projeto de Lei n. 4.148/08, de autoria do Deputado Federal Luiz Carlos Heinze.
} 
consumidor, como também - e sobretudo - busca esvanecer o debate acerca dos alimentos transgênicos no Brasil, já que, com isso, cada vez menos pessoas identificarão o próprio consumo de alimento geneticamente modificado e isso certamente causará impacto no conhecimento da extensão, do grau e da urgência do risco em questão. Beck destaca que "o potencial político da sociedade de risco tem de se desdobrar e ser analisado numa sociologia e numa teoria do surgimento e da disseminação do conhecimento sobre os riscos" ${ }^{\prime 4}$. Se menos pessoas se dão conta de que ingerem alimentos transgênicos, menos debate haverá na sociedade a respeito do tema, e assim menos conhecimento sobre o risco haverá. Logo, a ameaça representada por esse tipo de produto perde força e urgência, permitindo que eles sejam produzidos cada vez em maiores quantidades e com cada vez menos entraves, até que estejam totalmente livres de qualquer tipo de restrição em solo nacional.

Não é por acaso que a campanha eleitoral do deputado Luis Carlos Heinze no ano de 2014 arrecadou mais de dois milhões de reais, conforme dados do Tribunal Superior Eleitoral ${ }^{41}$, e entre seus maiores doadores estão as agroindústrias, que são as que mais lucram com o cultivo e a venda de produtos geneticamente modificados. Tem novamente razão Beck quando diz que "riscos da modernização são big business"

Completa-se, então, o ciclo de politização dos riscos socialmente reconhecidos: na disputa definitória a respeito da extensão, da urgência e do grau dos riscos causados pelos alimentos transgênicos, os interesses econômicos do agronegócio sobrepujaram, ao menos na Câmara dos Deputados, os possíveis impactos ambientais e na saúde humana provenientes da ingestão de organismos geneticamente modificados ${ }^{43}$.

Ocorre que essa modificação legislativa viola e ofende frontalmente o princípio da

${ }^{40}$ BECK, Ulrich. Sociedade de risco: rumo a uma outra modernidade. p. 28.

41 As prestações de contas dos candidatos estão disponíveis ao publico no sítio eletrônico do TSE e podem ser acessadas pelo seguinte link: http://inter01.tse.jus.br/spceweb.consulta.receitasdespesas2014/abrirTelaReceitasCandidato.action.

${ }^{42}$ BECK, Ulrich. Sociedade de risco: rumo a uma outra modernidade. p. 28.

${ }^{43}$ O que não é novidade no Brasil, como denunciou Viviane Candeia Paz já no ano de 2012: "Percebe-se, pois, que os aspectos econômicos tem sido preponderantes quando o assunto em voga é a produção e comercialização da soja em nosso país. Com efeito, a soja é o principal produto de exportação no Brasil. Essa situação emerge no mercado internacional, de acordo com dados da Companhia Nacional de Abastecimento a média da participação brasileira na produção mundial no período de safras de 2005/06 a 2009/10, indica que o Brasil somente perde a liderança na produção da soja para os Estados Unidos, que possui 36\%, enquanto que o Brasil conta com $26 \%$. Dessa forma, os dados existentes acerca da importância do cultivo da soja em nosso país, confirmam a relevância do aspecto econômico a influenciar o embate jurídico. Essa realidade, que aliada à intensificação do agronegócio, tem sido determinante para que a liberação da soja transgênica seja hoje uma realidade no Brasil, muito embora persistam as incertezas quanto aos riscos do seu consumo, e, ainda pendam de maior efetividade a aplicabilidade prática da lei de rotulagem”. PAZ, Viviane Candeia. Tutela jurídica ambiental, transgenia e rotulagem notas sobre a regulação jurídica da biossegurança no Brasil à luz do caso da soja transgênica. Artigo apresentado na I Conferência Internacional Direito Ambiental, Transnacionalidade e Sustentabilidade (Abril de 2012). Revista Eletrônica Direito e Política, Programa de Pós-Graduação Stricto Sensu em Ciência Jurídica da UNIVALI, Itajaí, v.7, n.2, $2^{\circ}$ quadrimestre de 2012. Disponível em: www.univali.br/direitoepolitica. 
sustentabilidade, já que, enquanto não houver um consenso científico mínimo a respeito da segurança dos alimentos geneticamente modificados, sua utilização indiscriminada é a negação da eticidade, da empatia e da solidariedade intergeracional que marcam esse novo paradigma axiológico e (também) jurídico, sobretudo porque pode dar azo a um enorme impacto socioambiental de dimensões planetárias - e vale lembrar que também esse risco possui o efeito bumerangue.

\section{CONSIDERAÇÕES FINAIS}

O Projeto de Lei n. 4.148/08, recentemente aprovado pela Câmara dos Deputados, que altera significativamente a forma de indicação nos rótulos de produtos que tenham em sua composição material transgênico, pode ser analisado sob outros prismas que não só o de violação ao direito do consumidor, porque está inserido em outros contextos ainda mais complexos e mais perniciosos para o ser humano.

Registra-se que, a sustentabilidade surge como novo paradigma axiológico transnacional, mais ético, solidário e humano, como tentativa de resposta à crise socioambiental criada pelo próprio homem em sua relação com a natureza. A sustentabilidade, assim, exige uma mudança de mentalidade com vistas à construção de uma nova ordem econômica (mais equilibrada), social (mais justa) e ambiental (que proteja a vida humana na Terra de forma sustentável e digna).

Assim, a sociedade de risco, fruto da utilização indiscriminada dos recursos naturais e do progresso do conhecimento científico, faz a humanidade deparar-se com ameaças de catástrofes socioambientais que colocam em dúvida a sustentabilidade da vida na Terra. Esse novo modelo de sociedade pode ser entendido a partir de cinco teses centrais, quais sejam: riscos são diferentes de riquezas; riscos possuem efeito bumerangue; riscos civilizatórios são um barril de necessidades sem fundo; na sociedade de risco, é a consciência que determina a existência; e as catástrofes têm potencial político (a politização dos riscos socialmente reconhecidos).

É nesse contexto que emergem as disputas definitórias não apenas acerca da existência das ameaças, mas sobretudo em torno da extensão, do grau e da urgência dos riscos. Nessas disputas não importam apenas eventuais problemas de saúde resultantes daquele risco concreto, mas sobretudo os efeitos colaterais sociais, econômicos e políticos do reconhecimento social da ameaça: a disputa é inserida na lógica de mercado e, ao fim, importa mesmo é quem perde e quem lucra com esse risco.

O PL 4.148/08 é um nítido e claro exemplo de disputa definitória de riscos socialmente reconhecidos, em que os interesses econômicos do agronegócio, representados no 
autor do projeto, Deputado Federal Luis Carlos Heinze, foram postos acima dos possíveis impactos ambientais e na saúde humana provenientes da ingestão de organismos geneticamente modificados. Entretanto, a modificação legislativa não se sustenta à luz do paradigma da sustentabilidade, por representar um retrocesso socioambiental e uma ameaça à construção desse novo imperativo ético.

Espera-se, por fim, que o Senado Federal rejeite esta modificação legislativa, preservando o direito dos consumidores, o princípio da sustentabilidade e invertendo a perversa equação que foi produzida na Câmara dos Deputados na disputa definitória do risco representado pelos alimentos transgênicos.

\section{REFERÊNCIAS}

BAGGIO, Andreza Cristina; EFING, Antônio Carlos. INFORMAÇÃO PARA O CONSUMO DE ALIMENTOS TRANSGÊNICOS: ATENDIMENTO DA DIGNIDADE DO CIDADÃO BRASILEIRO. Novos Estudos Jurídicos, [S.1.], v. 14, n. 2, p. 54-83, out. 2009. ISSN 21750491. Disponível em: 〈http://www6.univali.br/seer/index.php/nej/article/view/1768/1408>

BECK, Ulrich. Sociedade de risco: rumo a uma outra modernidade. São Paulo: Editora 34, 2011.

BOFF, Leonardo. Sustentabilidade: O que é - O que não é. 2. ed. Petrópolis, Rio de Janeiro: Vozes, 2013.

CAPRA, Fritjof. O ponto de mutação. São Paulo: Cultrix, 2012.

\section{Câmara aprova lei que dispensa símbolo da transgenia em}

rótulos.

Disponível

em:

http://brasil.elpais.com/brasil/2015/04/29/politica/1430318732_866908.html.

FERRER, Gabriel Real; GLASENAPP, Maikon Cristiano; CRUZ, Paulo Márcio. Sustentabilidade: um novo paradigma para o direito. Novos Estudos Jurídicos, [S.1.], v. 19, n. 4, p. 1433-1464, dez. 2014. ISSN 2175-0491. Disponível em: <http://www6.univali.br/seer/index.php/nej/article/view/6712/3833>.

FREITAS, Juarez. Sustentabilidade: direito ao futuro. 2. ed. Belo Horizonte: Fórum, 2012. p. 40. 
Câmara aprova projeto que muda rótulo de produtos transgênicos. Disponível em: http://g1.globo.com/politica/noticia/2015/04/camara-aprova-projeto-que- mudarotulo-de-produtos-transgenicos.html.

HUNTIGTON, Samuel P. Choque de civilizaciones?: texto crítico de Pedro Martinez Montávez. Madrid: Tecnos, 2002.

MARX, Karl; ENGELS, Friedrich. A ideologia alemã. 3. ed. São Paulo: Martins Fontes, 2007. p. $19-20$

ORSELLI, Helena Maria Zanetti de Azeredo e ARAUJO, Roseana Maria Alencar de. Estados transnacionais: aspectos destacados da proposta de Ulrich Beck. Revista Eletrônica Direito e Política, Programa de Pós-Graduação Stricto Sensu em Ciência Jurídica da UNIVALI, Itajaí, v.7, n.3, $3^{\circ}$ quadrimestre de 2012. Disponível em: www.univali.br/direitoepolitica

PAZ, Viviane Candeia. Tutela jurídica ambiental, transgenia e rotulagem notas sobre a regulação jurídica da biossegurança no Brasil à luz do caso da soja transgênica. Artigo apresentado na I Conferência Internacional Direito Ambiental, Transnacionalidade e Sustentabilidade (Abril de 2012). Revista Eletrônica Direito e Política, Programa de PósGraduação Stricto Sensu em Ciência Jurídica da UNIVALI, Itajaí, v.7, n.2, $2^{\circ}$ quadrimestre de 2012. Disponível em: $\underline{\text { www.univali.br/direitoepolitica. }}$

PRIEUR, Michel. O princípio da "não regressão" no coração do direito do homem e do meio ambiente. Revista de Estudos Jurídicos. v. 17, n. 1 (2012). Disponível em http://www6.univali.br/seer/index.php/nej/article/view/3634/2177

RAMMÊ, Rogério Santos. Justiça ambiental, marxismo ecológico e suas relações com o direito socioambiental. Revista Eletrônica Direito e Política, Programa de Pós-Graduação Stricto Sensu em Ciência Jurídica da UNIVALI, Itajaí, v.6, n.1, 1º quadrimestre de 2011.

Disponível em: www.univali.br/direitoepolitica.

Relatório da Comissão Mundial sobre Meio Ambiente e

Desenvolvimento. Relatório Brundtland, "Nosso Futuro Comum. Disponível em: http://www.un.org/documents/ga/res/42/ares42-187.htm. Acesso em: 15 de agosto de 2015.

SOUZA, Maria Cláudia da Silva Antunes de. Impressões sobre o legado da Rio+20. Revista Eletrônica Direito e Política, Programa de Pós-Graduação Stricto Sensu em Ciência Jurídica 
da UNIVALI, Itajaí, v.7, n.3, $3^{\text {o }}$ quadrimestre de 2012. Disponível em: www.univali.br/direitoepolitica. 